\title{
Yükseköğretimde Kahoot Kullanmak Ya da Kullanmamak: Öğretmen Adaylarının Kahoot'la Öğretime Yönelik Görüşleri ${ }^{1}$
}

\author{
Use or Not Use Kahoot in Higher Education: Prospective Teachers' \\ Opinions about Teaching with Kahoot
}

Murat Polat ${ }^{2}$

Alıntılama: Polat, M. (2019). Yükseköğretimde Kahoot kullanmak ya da kullanmamak: Öğretmen adaylarının Kahoot'la öğretime yönelik görüşleri. Ulusal Eğitim Akademisi Dergisi (UEAD), 3(2), 139-157.

Geliş tarihi:

5 Temmuz 2019

Kabul tarihi:

25 Eylül 2019

(C) UEAD 2019

Tüm hakları saklıdır.

Received:

5 July 2019

Accepted:

25 September 2019
Özet: $\mathrm{Bu}$ araştırmanın temel amacı derslerde bir öğretim materyali olarak Kahoot kullanımı hakkında öğretmen adaylarının görüşlerinin belirlenmesidir. Araştırma bir nitel araştırma olup; olgubilim deseninde yürütülmüştür. Araştırmanın çalışma grubunu toplamda 116 (71 kadın; 45 erkek) öğretmen adayı oluşturmaktadır. Araştırmada veri toplama aracı olarak yarı-yapılandırılmış bir görüşme formu kullanılmıştır. Araştırmaya katılan öğretmen adaylarının görüşleri yazılı olarak alınmış ve ulaşılan veriler üzerinde içerik analizi yapılmıştır. Yapılan içerik analizi sonunda elde edilen bulgular ise çeşitli kategoriler ve temalar altında birleştirilmiştir. Ayrıca ulaşılan bulgular, tablo, grafikler ve doğrudan alıntılama yoluyla paylaşılmıştır. Araştırma sonunda; öğretmen adaylarının derslerde Kahoot uygulamasının kullanımına yönelik görüşlerinin büyük oranda olumlu yönde olduğu tespit edilmiştir. Derslerde Kahoot kullanımına yönelik olumsuz görüş bildiren öğretmen adayı sayısı ise oldukça azdır. Öğretmen adaylarının Kahoot'a yönelik görüşlerinin en fazla araştırma kapsamında ortaya çıkan eğlence, algılanan fayda ve kullanma niyeti temalarında birleştiği ifade edilebilir. Bu bağlamda ilgili alanyazın çerçevesinde yükseköğretimde sınıf yönetimine dair birtakım öneriler de bulunulmuştur.

Anahtar kelimeler: yükseköğretim, sınıf yönetimi, online öğretme-öğrenme, kahoot, ögrretmen adayları.

Abstract: The main purpose of this study is to determine the opinions of prospective teachers about Kahoot use as a teaching material in the courses. The research is a qualitative research; is a phenomenology study. The study group consisted of 116 ( 71 females; 45 males) prospective teachers. The opinions of the prospective teachers were taken in writing and content analysis was performed on the data obtained. The findings obtained at the end of the content analysis were

1 Bu araştırma, 06-09 Aralık 2018 tarihinde Ankara'da yapılan I. Uluslararası İnsan Çalışmaları Kongresi’nde sözlü bildiri olarak sunulmuştur.

${ }^{2}$ Dr. Ögr. Üyesi, Muş Alparslan Üniversitesi, m.polat@alparslan.edu.tr, ORCID ID:0000-0002-2921-7831 
(C) UEAD 2019

All rights reserved. combined under various categories and themes. In addition, the findings were shared by tables, graphs and direct quotation. At the end of the research; It was determined that the opinions of prospective teachers on the use of Kahoot application in courses were mostly positive. The number of prospective teachers who reported negative views on using Kahoot is quite low. The opinions of prospective teachers about Kahoot use were combined under the themes of entertainment, perceived benefit and intention to use. In this context, the results of the research were discussed within the framework of the related literature and some suggestions were made about class management in higher education.

Keywords: higher education, classroom management, online teaching-learning, kahoot, prospective teachers.

\section{Giriş}

Öğretim teknolojileri alanındaki son gelişmeler, yükseköğretim kademesinde öğretim elemanları açısından sınıf yönetimini geçmişe kıyasla çok daha kolaylaştıran bir nitelik kazanmaya başlamıştır. Dahası öğretimin tüm kademelerinde yüz yüze sınıf yönetiminin her geçen gün daha güç olmaya başladığı günümüz sınıflarında öğretmenler ve öğrenciler için öğretim sürecini kolaylaştıran teknoloji temelli öğretim araçlarına duyulan ihtiyaç giderek daha da artmaktadır. Teknoloji temelli öğretim araçlarının sınıf yönetimini kolaylaştırıcı öğretim teknolojileri olarak öğrenciler üzerindeki olası etkilerinin neler olduğuna yönelik gerçekleştirilen farklı türden araştırmaların (Boden ve Hart, 2018; Dellos, 2015; Martins ve ark., 2019; Tan ve ark., 2019; Zarzycka-Piskorz, 2016) ise son 10 yılda giderek daha fazla sayıya ulaştığı söylenebilir.

\section{Kuramsal Çerçeve}

Konuya iliş̧kin yürütülmüş uluslararası alanyazındaki bazı araştırmalar, online öğretmeöğrenme teknolojileri, ortamları, uygulamaları ve araçlarının eğitimin hemen her kademesinden öğrencinin derse olan ilgisini oldukça artırabileceği (Aleksıc-Maslac ve Ark., 2017; Alvarado, Coelho ve Dougherty, 2016; Avcı ve Coşkuntuncel, 2019; Damarwan ve Khairudin, 2017; Dellos, 2015; Johns, 2015; Licorish ve Ark., 2018; Sarkar, Ford ve Mando, 2017; Turan ve Göktaş, 2015; Twymana ve Heward, 2015; Yapıcı ve Karakoyun, 2017) yönünde sonuçlar rapor etmektedir. Bu araştırma sonuçları incelendiğinde online öğretme-öğrenme teknolojileri arasında özellikle kullanıcı dostu yapısı ve görsel öğeleriyle, Kahoot uygulamasının birçok açıdan daha çok öne çıktığı (Graham, 2015; Bicen ve Karakoyun, 2017) ifade edilebilir. 
Yükseköğretimde Kahoot Kullanmak Ya Da Kullanmamak: Öğretmen Adaylarının Kahoot'la Öğretime Yönelik Görüşleri

Kahoot uygulamasının öğretmene/öğretim elemanına eğitimde farklı konu ve kavramların öğretimi süreçlerinde sağladığı öngörülen olumlu etkileriyle alakalı araştırmalar ise hâlen yürütülmektedir. Örneğin Yapıcı ve Karakoyun (2017) biyoloji öğretiminde oyunlaştırma başlı̆̆ı altında Kahoot'la biyoloji öğretimine yönelik biyoloji öğretmen adaylarının görüşlerini; Ares ve ark. (2018) Kahoot'la kimya öğretimi konusunda Kimya öğrencilerinin algılarını; Tsihouridis, Vavougios ve Ioannidis (2017) basit elektrik devrelerinin ortaokul öğrencilerine Kahoot'la öğretimini; Buzko ve Echkalo (2017) öğrencilere fizik öğretiminde Kahoot kullanımını; Medina ve Hurtado (2017) İngilizce yabancı dil sınıflarında Kahoot kullanımını ve Zarzycka-Piskorz (2016) öğrencilere gramer (dil bilgisi) öğretiminde Kahoot kullanımını araştırmışlardır. Yine Stige (2016) öğrencilerin bilgi düzeylerinin eşitlenmesi ve aktif öğrenmenin gerçekleşmesi sürecinde Kahoot'la öğretim yapmanın önemine; Iwamoto ve ark. (2017) ise Kahoot'un öğrenci performansını artırmadaki rolüne dikkat çekmişlerdir. Ayrıca Sarkar, Ford ve Mando (2017) dijital yerlilerin sosyal öğrenme süreçlerindeki Kahoot'la öğretimin etkilerine vurgu yapmışlar ve Aleksıc-Maslac ve ark. (2017) ise Kahoot'la öğretimin öğrencilerin okul bağlılıklarına bir tür "pozitif dalga" etkisi yarattığını iddia etmişlerdir.

\section{Araştırmanın Önemi}

Yükseköğretimde dijital dönüşümün artık konuya vakıf tüm çevrelerce kabul gördüğü günümüzde, özellikle, üniversite düzeyinde yapılan yüz yüze öğretim süreçleri ve sınıf yönetimi açısından göz ardı edilemez bir sürece girdiği ortadadır. Bu konuda ters yüz edilmiş sınıf ortamları başta olmak üzere birçok farklı ve teknoloji temelli alternatif yaklaşımın benimsendiği şimdi ve geleceğin sınıf yönetimi açısından belirtilebilir. $\mathrm{Bu}$ anlamda öne çıkan bireyselleştirilmiş oyun temelli öğrenme durumu ve bu amaçla geliştirilmiş olan Kahoot ve benzeri oyunlaştırma araçlarının önemi ise her geçen gün giderek artmaktadır. Burada özellikle Türkiye'deki üniversite öğrencileri örnekleminde Kahoot'la ilgili çalışmaların sınırlı sayıda olması ise dikkat çekmektedir. Dolayısıyla üniversite öğrencilerinin Kahoot'la ilgili bakış açılarını ele alan bu çalışmanın ilgili alanyazına ve bu konudaki eğilimlere bir katkı sağlayacağı öngörülebilir.

Araştırmanın Amacı 
$\mathrm{Bu}$ araştırmanın temel amacı derslerde bir öğretim materyali olarak Kahoot kullanımı hakkında öğretmen adaylarının (Fen Bilgisi, Matematik, Psikolojik Danışma ve Rehberlik ile Sosyal Bilgiler öğretmenliği) görüşlerinin belirlenmesidir.

1. Öğretmen adaylarının derslerde Kahoot uygulamasının kullanımına yönelik görüşleri (olumlu-olumsuz) nasıldır?

2. Öğretmen adaylarının derslerde Kahoot'un daha etkili nasıl kullanılabileceğine dair görüşleri nelerdir?

3. Öğretmen adayları gelecekte kendi derslerinde de Kahoot'a benzer uygulamaları kullanmayı istemekte midirler?

\section{Yöntem}

Çalışmada, nitel araştırma desenlerinden olgubilim deseni kullanılmıştır. Olgubilim deseni, araştırmacının aslında farkında olduğu ancak hakkında derin bilgiye sahip olmadığı olguları incelemek için kullanılır (Yıldırım ve Şimşek, 2006). Bu araştırma kapsamında da online bir öğretme-öğrenme aracı olarak Kahoot'un 2018-2019 akademik y1lı güz döneminde araştırmacının kendisi tarafından verilen "Eğitime Giriş" dersindeki öğretim süreci üzerindeki etkileri araştırılmaya çalışılmıştır. Buna göre araştırmada bir yöntem olarak; Kahoot'un farkında olunan yarattığı olası etkilerinin dört farklı anabilim dalından öğretmen adaylarının görüşleri alınarak ortaya konulması amaçlandığından olgubilim deseni tercih edilmiştir.

\section{Çalışma Grubu}

Araştırmanın çalışma grubunu 2018-2019 eğitim-öğretim yllı güz döneminde Muş Alparslan Üniversitesi Eğitim Fakültesinde birinci sınıfa kayıtlı olan ve "Eğitime Giriş" dersini alan 116 öğretmen adayı oluşturmaktadır. Çalışma grubu belirlenirken, amaçlı örnekleme yöntemlerinden 'Benzeşik Örnekleme Yöntemi”' tercih edilmiştir. Benzeşik örneklemenin temel amacı, analizi basitleştirmek, çeşitliliği azaltmak, odaklanmak ve grup görüşmelerini daha kolay hale getirmektir (Baltacı, 2018) Başka bir deyişle bu örnrkleme yönteminde çalışma grubu; evrende yer alan ve araştırmanın problemiyle ilgili olan denk bir alt gruptan ya da durumdan oluşturulur (Büyüköztürk, 2012). Çalışma grubuna ilişkin demografik bilgiler Şekil 1 ve 2'de paylaşılmıştır. Buna göre katılımcıların yaklaşık üçte ikisini kadın öğretmen adayları oluşturmaktadır. Araştırmaya Fen Bilgisi (1), Matematik (31), Psikolojik Danışma ve Rehberlik 
(44) ile Sosyal Bilgiler (40) öğretmenliği olmak üzere dört farklı anabilim dalından katılım olmuştur. En büyük oranda katılım ise öğrenci sayısının diğer anabilim dallarına oranla daha yüksek sayıda olduğu Psikolojik Danışma ve Rehberlik anabilim dalından olmuştur.

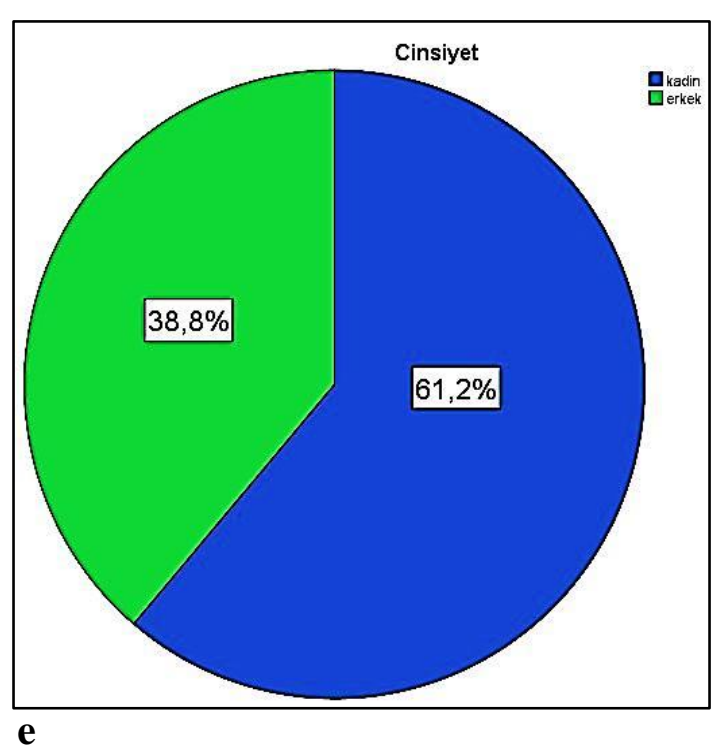

kil 1. Çalışma Grubundaki Katılımclların Cinsiyetlerine Göre Dağllımları

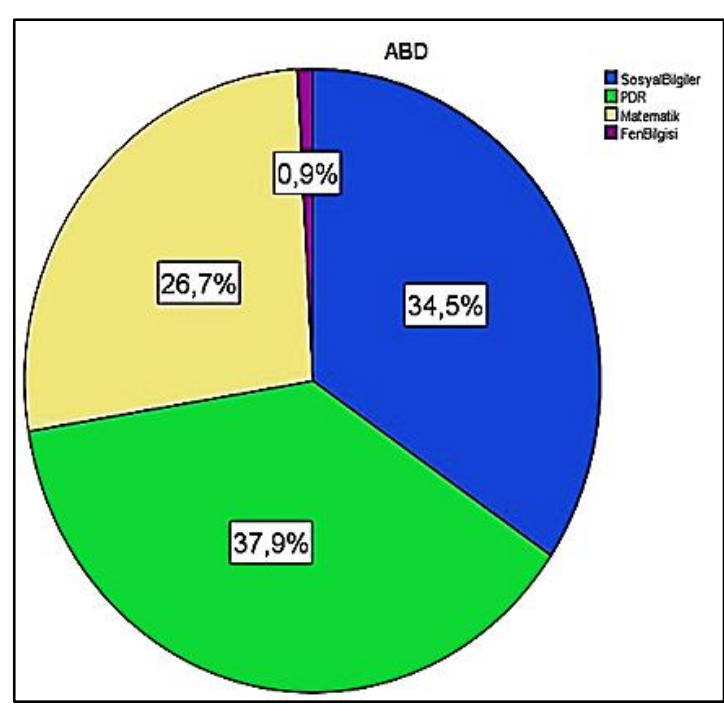

Şekil 2. Çalışma Grubundaki Katılımcıların Kayıtlı Oldukları Anabilim Dalına Göre Dă̆llımları

\section{Veri Toplama Aracı ve Kodlama Süreci}

Araştırmada veri toplama aracı olarak araştırmacının kendisi tarafından hazırlanan bir adet yarı-yapılandırılmış görüşme formu kullanılmıştır. Görüşme formu yardımıyla şu sorulara yanıt aranmaya çalışılmıştır: Öğretmen adaylarının derslerde Kahoot uygulamasının kullanımına yönelik görüşleri (olumlu-olumsuz) nasıldır? Öğretmen adaylarının derslerde Kahoot'un daha etkili nasıl kullanılabileceğine dair görüşleri nelerdir? Öğretmen adayları gelecekte kendi derslerinde de Kahoot'a benzer uygulamaları kullanmayı istemekte midirler? Formun hazırlanması sürecinde iki ayrı uzman öğretim üyesinden (öğretim teknolojileri ve eğitim yönetimi bölümünden) görüşleri alınmıştır. Uzman görüşleri neticesinde araştırma sorularına son hâli verilmiştir. Böylece hazırlanan görüşme formu, üç adet kişisel sorudan oluşan bir demografik bilgiler anketi ile iki adet açık uçlu soru ve bir adet kapalı uçlu sorudan oluşmaktadır. Öğrenci görüşleri, 2018-2019 eğitim-öğretim y1lı güz döneminde, Kahoot'la öğretimin gerçekleştirildiği 
araştırmacının kendisi tarafından yürütülen Eğitime Giriş dersi kapsamında, her anabilim dalı için ayrı zaman dilimlerinde, bir defada ve yazılı olarak alınmıştır. Eğitim Fakültesi birinci sınıftaki öğretmen adaylarına, gerçekleştirilen bu çalışmaya katılımın zorunlu olmadığı ve etik açıdan yazacakları her şeyin sadece araştırma amaçlı kullanılacağı etraflıca açıklanmıştır. Bu anlamda öğrencilerden kendilerini rahat hissetmeleri istenmiştir.

Verilerin kodlanması sürecine ilk olarak katılımcı kodlarının oluşturulması ile başlanmıştır. Buna göre örnek bir katılımcı kodu şu şekildedir: "SE2”. Burada en baştaki harf olan "S: Sosyal Bilgiler" öğrencinin anabilim dalını, ortadaki harf olan "E: Erkek" katılımcının cinsiyet durumunu ve en sondaki "2" rakamı ise katılımcıya atanan katılımcı numarasını temsil etmektedir. Yapılan katılımcı kodlaması sonrasında öğretmen adaylarının görüşleri araştırmacının kendisi tarafından bir ön incelemeye tabi tutulmuş ve oluşturulacak olası temalara ilişkin bir liste hazırlanmıştır. Hazırlanan tema listesinde bulunan temalar arasında öğrenci görüşlerinin en çok yoğunluk kazandığı temalar için bir eleme yapılmış ve seçilen temalar için alt temalar belirlenmeye çalışılmıştır.

\section{Verilerin Analizi}

Ulaşılan katılımcı öğretmen adaylarının görüşleri üzerinde içerik analizi yapılmış ve öne çıkan görüşler tema, alt temalar ve doğrudan alıntılama yoluyla önceden oluşturulan katılımcı kodlarıyla birlikte paylaşılmıştır. Verilerin analizi sürecinde Saban (2009) tarafından önerilen; kodlama ve ayıklama aşaması, derleme aşaması, tema geliştirme aşaması, geçerlik ve güvenirlik aşaması (Doğrudan alıntılama yapılmış; Miles ve Huberman'ın (1994: 64) formülü [Güvenirlik=görüş birliği/(görüş birliği+görüş ayrılığı)*100], ulaşılan bulguların grafik ve tablolara dökülmesi aşaması izlenmiştir. Verilerin analizinde Excel ofis programından yararlanılmıştır.

\section{Araştırmanın Geçerlik ve Güvenirliği}

Ulaşılan verilerin güvenirlik değeri için araştırmacının kendisi ve bir alan uzmanı tarafından yapılan değerlendirmelerin neticesinde, bulguların uyuşumu açısından büyük oranda benzerlik $(\% 87,1)$ yakalanmıştır. Ayrıca katılımcı görüşlerinin genel olarak olumlu ve olumsuz olmak üzere iki ayrı kategoride toplandıkları tespit edilmiştir. Ulaşılan tüm tema ve alt temalar ile kategorik veriler bir başka alan uzmanına daha gönderilmiş ve araştırmanın kapsamı açısından 
Yükseköğretimde Kahoot Kullanmak Ya Da Kullanmamak: Öğretmen Adaylarının Kahoot'la Öğretime Yönelik Görüşleri

uygun olup olmadıklarına karar verilmeye çalışılmıştır. Dolayısıyla alınan alan uzmanı görüşü ve ulaşılan büyük benzerlik oranı ile araştırma bulgularına dair geçerlik ve güvenirliğin (İnandırıcılık, tutarlık, aktarılabilirlik, dış güvenirlik, teyit edilebilirlik gibi) sağlanmış olduğu söylenebilir.

\section{Bulgular ve Yorum}

Araştırma sonunda ulaşılan bulguların tümü, veri paylaşımında açıklık ilkesi gereği daha anlaşılır olmak adına ilgili araştırma problem cümlesinin alt başlıklar şeklinde kullanılması biçiminde bu bölümde sunulmuştur.

Öğretmen adaylarının derslerde Kahoot uygulamasının kullanımına yönelik görüşleri (olumlu-olumsuz) nasildır?

Araştırmaya katılan öğretmen adaylarının derslerde Kahoot uygulamasının kullanımına yönelik görüşleri, öncelikle Tablo 1'de kategorik olarak analiz edilmiş ve sonrasında Tablo 2'de tematik olarak gösterilmiştir.

Tablo 1. Öğretmen Adaylarının Derslerde Kahoot Uygulamasının Kullanımına Yönelik Görüşlerinin Kategorik Analizi

\begin{tabular}{|c|c|c|c|}
\hline Kategori & Öne Çıkan Doğrudan Alıntı & f & $\%$ \\
\hline Olumlu & $\begin{array}{l}\text { "Teknolojinin imkanlarından yararlanıyoruz." SE14 } \\
\text { "Bence Kahoot uygulaması oldukça faydalı." PK66 } \\
\text { "Dersin daha iyi işlenmesine yardımcı oluyor.” PK77 } \\
\text { "Bence çok faydalı oluyor.” MK87 } \\
\text { "Kesinlikle faydalı, dersi en iyi şekilde öğrenmemizi sağlıyor.” ME95 } \\
\text { "Gayet başarılı bir uygulama" ME111 }\end{array}$ & 75 & 64.7 \\
\hline Olumsuz & $\begin{array}{l}\text { "İnternetimizi bitiriyor.” ME93; MK115; ME113; ME110; PK60; SK18 } \\
\text { "Teknolojiye çok bağlı kalınması iyi değil.” MK104 } \\
\text { "Sinıfta fazla gürültü olmasına neden oluyor.” MK103 } \\
\text { "Sınıfta rekabetçi bir ortam oluyor, o zamanlarda sağlılı düşünemiyor.” MK103 } \\
\text { "Teknoloji ile ilgili olmayan kişiler dersten kopuyor" PE85 } \\
\text { "Zamanın kısıtlı olması bir sorun.” PK73 } \\
\text { "İnternetsiz çalışamaması kötü...Kahoot'u internetten açmak süre kaybına neden } \\
\text { oluyor.” PK53 } \\
\text { "Öğrenciler arasında çekememezlik duygusunu doğuruyor.” SE39 } \\
\text { "Bizim teknolojiye yönelmemiz bizi tembelleştirir.” SK18 } \\
\text { "Gönüllü katılım olması kötü, herkes katılmıor.” MK88 } \\
\text { "Öğrenciler Kahoot dışında farklı uygulamalara da girebilirler.” MK90 }\end{array}$ & 41 & 35.3 \\
\hline
\end{tabular}

Tablo 1 incelendiğinde, araştırmaya katılan öğretmen adaylarının derslerde Kahoot uygulamasının kullanımına yönelik kategorik görüşlerinin oldukça büyük oranda olumlu yönde 
olduğu anlaşılmaktadır. Bu durumu, ME95 kodlu ilköğretim matematik öğretmenliğinden bir erkek katılımcı "Kesinlikle faydalı, dersi en iyi şekilde öğrenmemizi sağlıyor." şeklinde vurgularken, PK77 kodlu psikolojik danışma ve rehberlik anabilim dalından kadın bir katılımeı ise "Dersin daha iyi işlenmesine yardımcı oluyor." diyerek açıklamaktadır.

Diğer yandan araştırma sorusuna kategorik olarak olumsuz görüş bildiren katılımcı görüşlerinin ise genellikle "İnternetimizi bitiriyor." (ME93; MK115; ME113; ME110; PK60; SK18) şeklinde bir ortak serzenişte bulunan farklı anabilim dallarından kadın ve erkek öğretmen adayları oldukları görülmektedir. Burada öğrencilerin ders esnasında Kahoot'a kendi cep telefonları üzerinden dâhil olmalarının bu ortak beyanları üzerinde büyük oranda önemli bir etken olduğu ifade edilebilir. Çünkü sınıfta paylaşımlı bir ortak eduroam ağı olmadığından öğretmen adayları, ders boyunca kendi internet tarifeleri üzerinden Kahoot etkinliklerine katılmışlardır. Ayrıca bu kategoride görüş bildiren kimi katılımcılar arasında derslerde sınıf iklimi açısından Kahoot'un olumsuz rekabet koşulları oluşturduğuna (SE39), gürültülü bir sınıf ortamına zemin hazırladığına (MK103), teknolojiye bağımlılık yaratabileceğine (SK18) ve kimi zaman dikkati dağıtan bir rol oynayabileceğine (MK90) işaret eden katılımcılar olduğu da söylenebilir. 
Yükseköğretimde Kahoot Kullanmak Ya Da Kullanmamak: Öğretmen Adaylarının

Kahoot'la Öğretime Yönelik Görüşleri

Tablo 2. Öğretmen Adaylarının Derslerde Kahoot Uygulamasının Kullanımına Yönelik Görüşlerinin Tematik Analizi

\begin{tabular}{|c|c|c|c|c|}
\hline Tema & Alt Tema & Öne Çıkan Doğrudan Alıntı & f & $\%$ \\
\hline Öğretim & $\begin{array}{l}\text { Eğlence; Tekrar; } \\
\text { Pekiştirme; } \\
\text { Hatırlatma; } \\
\text { Teknolojiyi işe } \\
\text { koşma/Entegrasyon } \\
\text {; Keyif; Dikkati } \\
\text { çekme; } \\
\text { Bireyselleştirme }\end{array}$ & $\begin{array}{l}\text { "Eğitimde teknoloji kullanılıyor, bu iyi bir şey” MK88, PK67 } \\
\text { "Bilgilerimizi tekrarlamamızı ve unutmamamızı sağlıyor.” MK101 } \\
\text { "Ak1llı telefondan giriş yapabildiğimiz için eğlenceli bir uygulama } \\
\text { olduğunu düşünüyorum.” SK3 } \\
\text { "Ders daha eğlenceli geçiyor.” SK28 } \\
\text { "Derste öğrendiğimiz bilgilerin pekişmesini sağlıyor.” PK52 } \\
\text { "Öğrencinin kendi telefonuyla bağlanmas1 ve kendine doğru gelen } \\
\text { ş1kk1 işaretlemesi doğruyu yanlışı fark etmesini sağlıyor.” ME99 }\end{array}$ & 80 & 69 \\
\hline $\begin{array}{l}\text { Etkili } \\
\text { Öğrenme }\end{array}$ & $\begin{array}{l}\text { Anlama; Kavrama; } \\
\text { Motivasyon; İstek; } \\
\text { Konsantrasyon; } \\
\text { Eksikleri Görme; } \\
\text { Kolaylık; Hız; } \\
\text { Merak; Bilginin } \\
\text { Kalıcılığ1/Akılda } \\
\text { Kalıcılık; Uyum; } \\
\text { Bilgiyi Ölçme; } \\
\text { Sınavlara Hazırlık; } \\
\text { Sinıf İçi Etkileşim }\end{array}$ & $\begin{array}{l}\text { ”Öğrenme daha hızlı oluyor.” ME97 } \\
\text { "Dersteki konuları merak etmemizi sağlıyor." ME98 } \\
\text { "Çok faydalı, hırs yapıyorum.” SK7 } \\
\text { "Büyük bir faydası var, öğrencilerin derse motive olmasını } \\
\text { sağlıyor." SK16 } \\
\text { "Dikkat ve odaklanmama pozitif yönde etki ediyor" PE51 } \\
\text { "Çağa ayak uyduruyoruz.” MK91 } \\
\text { "Bilgilerin kalıcı olmasını sağlıyor.” ME93 } \\
\text { "Ders konuları hakkında ne kadar bilgi sahibi olduğumuzu } \\
\text { gösteriyor." MK102 } \\
\text { "Sınava hazırlı için yararlı bir uygulama." SK10 } \\
\text { "Sınıftaki etkileşimi artırıyor. Bu da akılda kalıcı bir öğrenme } \\
\text { sağlıyor." SE12 } \\
\text { "Ders daha verimli geçiyor. Daha samimi bir ortam oluşuyor." } \\
\text { PK66 }\end{array}$ & 54 & 46.6 \\
\hline Katılım & $\begin{array}{l}\text { Derse Katılım; } \\
\text { Rekabet; Derse } \\
\text { Hazırlıklı Gelme; } \\
\text { Yarışma; Aktif } \\
\text { Katılım }\end{array}$ & $\begin{array}{l}\text { "Sırf Kahoot'taki soruları bilmek için önceki hafta işlediğimiz } \\
\text { konuları çalışıp, not çıarıp baktım.” MK103 } \\
\text { "Herkesin ortak olarak derse katılmasını sağlıyor.” SE17 } \\
\text { "Derste daha aktif olmamızı sağlıyor.” SK21 } \\
\text { "Derse hazırlıklı gelme oranını arttırıyor.” PE46 }\end{array}$ & 25 & 21.6 \\
\hline
\end{tabular}

Tablo 2'ye göre öğretmen adaylarının Kahoot'un derslerde kullanımına yönelik görüşlerinin temelde üç farklı tema (Öğretim, Etkili Öğrenme, Katılım) ve bu temalara bağlı olarak 28 ayrı alt temada toplandığı tematik açıdan ifade edilebilir. Burada katılımcı görüşleri doğrultusunda en çok öne çıkan ana temanın "Öğretim” teması olduğu ( $\mathrm{f}=80)$ görülmektedir. Bu tema altındaki alt temaların ise "Eğlence; Tekrar; Pekiştirme; Hatırlatma; Teknolojiyi İşe Koşma/Entegrasyon; Keyif; Dikkati Çekme; Bireyselleştirme” olarak tespit edildiği söylenebilir. Öğretim teması altında örneğin SK28 kodlu sosyal bilgiler öğretmenliği anabilim dalından kadın bir katılımcı Kahoot'un derslerde kullanımına yönelik olarak "Ders daha eğlenceli geçiyor." şeklinde görüşünü eğlence alt teması altında belirtirken, PK52 kodlu psikolojik danışma ve rehberlik anabilim dalından kadın bir öğretmen adayı ise "Derste öğrendiğimiz bilgilerin 
pekişmesini sağlıyor.” diyerek Kahoot'un derslerde kullanımına yönelik pekiştirme alt teması altında bir görüşünü açıklamaktadır.

Diğer taraftan araştırmaya katılan öğretmen adaylarının orta düzeyde bir oranla $(\mathrm{f}=54)$ görüşlerinin birleştiği temanın "Etkili Öğrenme” ana teması olduğu anlaşılmaktadır. Bu ana tema altında ise "Anlama; Kavrama; Motivasyon; İstek; Konsantrasyon; Eksikleri Görme; Kolaylık; Hız; Merak; Bilginin Kalıcılığı/Akılda Kalıcılık; Uyum; Bilgiyi ölçme; Sınavlara Hazırlık; Sınıf İçi Etkileşim” alt temalarının yer aldığı görülmektedir. Örneğin, motivasyon alt temasına uygun şekilde SK16 kodlu sosyal bilgiler anabilim dalından kadın bir katılımcı Kahoot'un derslerde kullanımına yönelik görüşünü "Büyük bir faydası var, öğrencilerin derse motive olmasını sağlıyor." diyerek beyan etmiştir. Yine SE12 kodlu sosyal bilgiler anabilim dalından erkek bir katılımcı da bilginin kalıcılığg/akılda kalıcılık alt temasına vurgu yaparcasına görüşünü "Sınıftaki etkileşimi artırıyor. Bu da akılda kalıcı bir öğrenme sağlıyor.” olarak açıklamıştır.

Katılımcı görüşleri açısından en az öne çıkan tema $(\mathrm{f}=25)$ ise "Katılım” temasıdır. $\mathrm{Bu}$ temaya bağlı olarak "Derse Katılım; Rekabet; Derse Hazırlıklı Gelme; Yarışma; Aktif Katılım” alt temalarının ortaya çıktığı anlaşılmaktadır. Katılım ana temasına bağlı alt temalar için örneğin MK103 kodlu ilköğretim matematik öğretmenliğinden kadın bir öğretmen adayının görüşünü "Sırf Kahoot'taki soruları bilmek için önceki hafta işlediğimiz konuları çalışıp, not çıkarıp baktım.” şeklinde derse hazırlıklı gelme alt teması altında ifade ettiği, SK21 kodlu sosyal bilgiler anabilim dalından başka bir kadın katılımcının ise görüşünü Kahoot'un derslerde kullanımına yönelik aktif katılım alt teması altında olacak şekilde "Derste daha aktif olmamızı sağlıyor." olarak beyan ettiği söylenebilir.

Araştırmaya katılan öğretmen adaylarının Kahoot'un derslerde kullanımına yönelik tematik görüşleri, genel olarak Kahoot'un öğretime katkı yapan, etkili öğrenmeyi sağlayan ve derse katılımı artıran birtakım önemli çıktılarının olduğuna işaret etmektedir. Öğretmen adaylarının özellikle eğlenceli bir öğretim süreci geçirdikleri, derslerde daha aktif olmaya başladıkları ve bireysel öğrenme durumları açısından birçok olumlu duyguya kapıldıkları anlaşılmaktadır. Bu anlamda Kahoot'un derslerde kullanımının üniversite öğrencilerinin yüz yüze derslerdeki performanslarını geliştirme açısından olası olumlu ve önemli etkilerinin olabileceği öngörülebilir. 
Yükseköğretimde Kahoot Kullanmak Ya Da Kullanmamak: Öğretmen Adaylarının Kahoot'la Öğretime Yönelik Görüşleri

Öğretmen adaylarının derslerde Kahoot'un daha etkili nasıl kullanılabileceğine dair görüşleri nelerdir?

Öğretmen adaylarının derslerde Kahoot'un daha etkili nasıl kullanılabileceğine dair görüşlerinin tematik analizi Tablo 3'te verilmiştir.

Tablo 3. Öğretmen Adaylarının Derslerde Kahoot’un Daha Etkili Nasıl Kullanılabilecĕgine İlişkin Tematik Görüşleri

\begin{tabular}{|c|c|c|c|}
\hline Tema & Öne Çıkan Doğrudan Alıntı & f & $\%$ \\
\hline Zaman & $\begin{array}{l}\text { “S1k s1k yapılmalı.” SK11, SE14 } \\
\text { "Sürekli ve devamlı yapılmalı.” SK15 } \\
\text { "Soruları düşünmek için daha fazla zaman verilmeli.” SE30 } \\
\text { "Derslerde ayrılan süre arttır1lsa daha iyi olur.” PE51 } \\
\text { "Dersin süresi arttırılsa daha fazla kullanabiliriz.” PE55 } \\
\text { "Çok çabuk sona eriyor.” PK66 } \\
\text { "Özzellikle sınıf s1kıldığ1 zaman kullanılması gerekli.” ME96 }\end{array}$ & 8 & 6.9 \\
\hline Görsellik & $\begin{array}{l}\text { "Video olsa iyi olabilir." PK49, PK58 } \\
\text { "Sesli soru özelliği getirilebilir, video eklenebilir." PK56 }\end{array}$ & 4 & 3.4 \\
\hline İçerik & $\begin{array}{l}\text { "Sorulan soru sayısı arttırılmalı.” PK67, PK87, ME94 } \\
\text { "Farklı ve daha eğitici etkinlikler de eklenebilir.” MK107 } \\
\text { "Soru çeşitleri arttırılsı.." SK6 } \\
\text { "Daha ilginç konular da sorulsun.” FK35 } \\
\text { "Quiz gibi olsun, alınan puanlar notlara eklensin.” PE47 } \\
\text { "Daha fazla içerik eklenebilir.” PK74 }\end{array}$ & 46 & 39.7 \\
\hline Kullanım & $\begin{array}{l}\text { “Tüm derslerde kullanılmalı.” PK67, PK83, ME99 } \\
\text { "Dersin sonunda da kullanılmalı.” PE75 } \\
\text { "Desten sonra da erişilebilsin.” PE81 } \\
\text { "Derslerde kullanılırken her öğrenciye internet açılmalı.” MK89 } \\
\text { "Ders esnasında ara ara kullanılabilir.” ME112 } \\
\text { "Hem dersten önce hem de dersten sonra kullanılmalı.” SK10 } \\
\text { "Her eğitim kademesinde kullanılmas1 daha güzel olur.” SK25 } \\
\text { "Sözlü katılımla münazara şeklinde de kullanılabilir.” PK59 }\end{array}$ & 36 & 31 \\
\hline
\end{tabular}

Tablo 3'te görüldüğü üzere öğretmen adaylarının Kahoot'un derslerde daha etkili nasıl kullanılabileceğine ilişkin tematik görüşlerinin “Zaman, Görsellik, İçerik ve Kullanım” olmak üzere dört ayrı tema altında birleştiği belirtilebilir. Buna göre "Zaman" teması altında ( $\mathrm{f}=8)$ öne çıkan görüşlerin “Özellikle sınıf sıkıldı̆̆ı zaman kullanılması gerekli.” (ME96), "Soruları düşünmek için daha fazla zaman verilmeli." (SE30) ve "Sürekli ve devamlı yapılmalı." (SK15) şeklinde olduğu görülmektedir. Bu bağlamda öğretmen adaylarının tematik görüşlerinin Kahoot için derslerde daha fazla zaman ayrılması yönünde olduğu ifade edilebilir. Ayrıca derslerinde 
Kahoot kullanan öğretim elemanları, hazırladıkları quiz ve benzeri etkinliklerdeki sorular için önceden planladıkları cevaplama sürelerini grubun isteğine göre dilerlerse biraz daha artırabilirler.

Kahoot'un derslerde daha etkili nasıl kullanılabileceğine ilişkin tematik görüşler arasında en az öne çıkan temanın ise "Görsellik" teması olduğu söylenebilir ( $\mathrm{f}=4)$. Bu temaya ilişkin görüşlerin "Video olsa iyi olabilir." (PK49, PK58) ve "Sesli soru özelliği getirilebilir, video eklenebilir." (PK56) şeklinde öne çıktığı görülmektedir. Kahoot'un derslerde kullanımında video ekle seçeneği bulunmaktadır. Ancak hem görsel olarak yetersiz olduğundan hem de video içerisine soru ekleme seçeneği bulunmadığından öğretim için çok kullanışlı olmadığı ve kimi katılımcı görüşlerinin bu doğrultuda olduğu söylenebilir.

Temalar arasında en çok öne çıkan temanın ise "İçerik" teması olduğu ( $\mathrm{f}=46)$ anlaşılmaktadır. Bu tema için örneğin PK74 kodlu psikolojik danışma ve rehberlik anabilim dalından bir kadın katılımcı "Daha fazla içerik eklenebilir." şeklinde görüşünü bildirirken, MK107 kodlu ilköğretim matematik öğretmenliğinden bir kadın öğretmen adayı ise "Farklı ve daha eğitici etkinlikler de eklenebilir.” önerisini getirmektedir. Kahoot'un ücretsiz kullanıma açık olan şablonları ve özelliklerinin artırılması veya fakültelerin öğretim elemanlarının kullanacağı online öğretme-öğrenme araçları için ayrı bir bütçe kalemi oluşturulması, içerik öğelerinin derslerde daha etkin kullanılmasının önünü açabilir.

"Kullanım" teması öğretmen adaylarının en çok görüş bildirdiği ikinci temadır ( $\mathrm{f}=36$ ). Katılımcıların görüşleri arasında örneğin "Tüm derslerde kullanılmalı.” (PK67, PK83, ME99) veya "Her eğitim kademesinde kullanılması daha güzel olur." (SK25) şeklinde derslerde Kahoot kullanımını oldukça teşvik edici önerilerin ortaya çıktığ ders sonunda hem de ders başında kullanılmasını vurgulayan öğretmen adayları bulunmaktadır (SK10, PE75, ME112). Katılımcılardan PK59 kodlu psikolojik danışma ve rehberlik alanından kadın bir katılımcı ise "sözlü katılım" da olsun şeklinde bir öneri getirmektedir.

Genel anlamda ele alındığında araştırmaya katılan öğretmen adaylarının Kahoot'un derslerde daha etkili nasıl kullanılabileceğine ilişkin tematik görüşlerinin özellikle içeriğin daha fazla zenginleştirilmesi noktasında birleştiği söylenebilir. Katılımcılar derslerde Kahoot'un daha sık kullanılması gerektiğine, bu yapılırken de zaman ve görsellik öğelerinin göz ardı edilmemesi gerektiğine dikkat çekmektedirler. 
Yükseköğretimde Kahoot Kullanmak Ya Da Kullanmamak: Öğretmen Adaylarının Kahoot'la Öğretime Yönelik Görüşleri

Öğretmen adayları gelecekte kendi derslerinde de Kahoot ve benzeri uygulamaları kullanmayt istemekte midirler?

Katılımc1 eğitim fakültesinin birinci sınıftaki öğretmen adaylarına yöneltilen kendi derslerinde Kahoot'a benzer uygulamaları kullanmayı isteyip istemedikleri yönündeki kapalı uçlu soruya verdikleri yanıtlara ilişkin dağılım yüzdeleri Şekil 3’te verilmiştir.

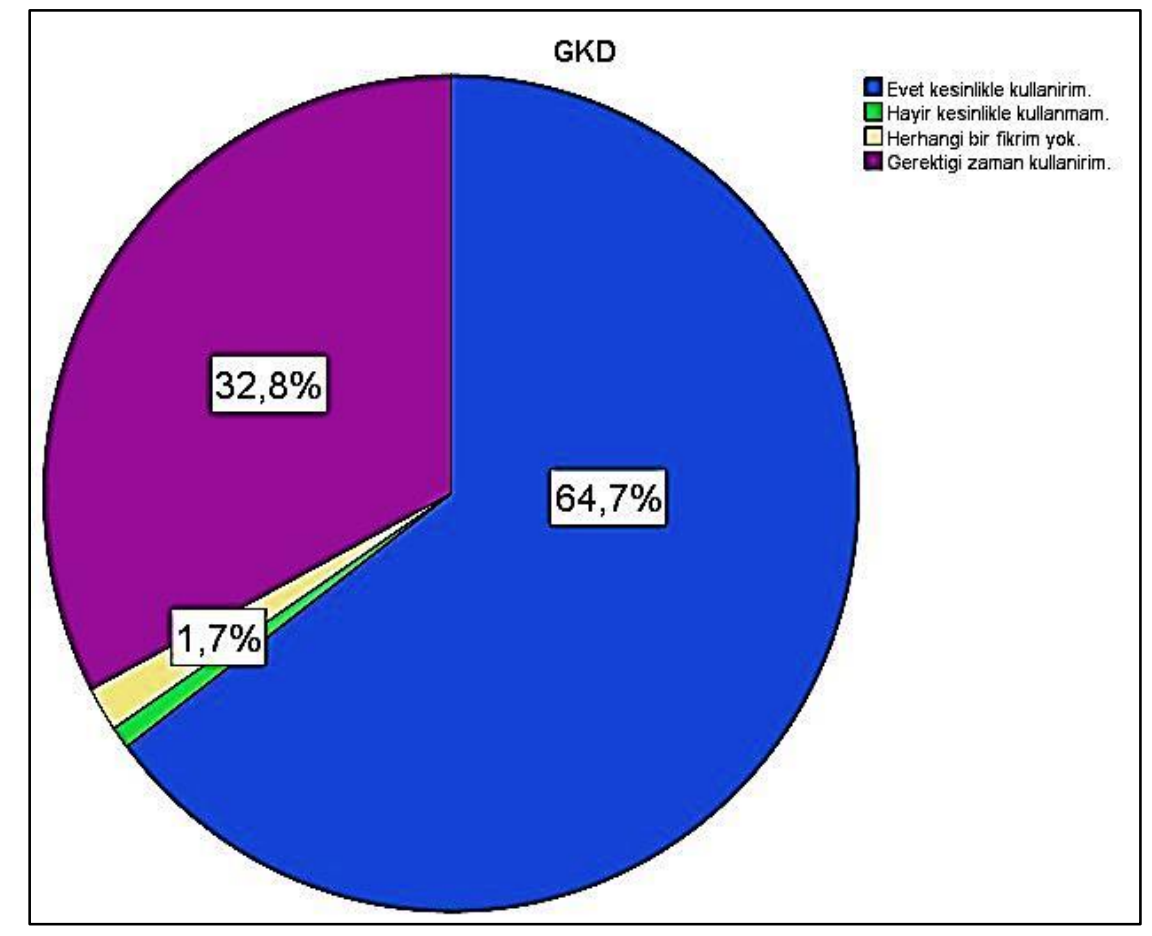

Şekil 3. Öğretmen Adaylarının Gelecekte Kahoot ve Benzeri Uygulamaları Kullanmaya Yönelik Bakış Açıları

Şekil 3 incelendiğinde, katılımcıların çok büyük bir oranla (\%65) "Evet Kesinlikle Kullanırım" seçeneğini işaretledikleri oldukça düşük bir yüzdeyle ise (\%2) "Hayır Kesinlikle Kullanmam" seçeneğini tercih ettikleri anlaşılmaktadır. Bunun yanı sıra katılımcı öğretmen adayları arasında bu araştırma sorusuna temkinli yaklaşanların da çoğunlukta olduğu gözlemlenmiştir. Buna göre katılımcıların yaklaşık \%33'lük bir dilimi sadece "Gerektiği Zaman" derslerinde Kahoot'u kullanmak isteyebilecekleri yönünde görüş belirtmişlerdir. Genel olarak bakıldığında ise araştırmaya katılan öğretmen adaylarının Kahoot ve benzeri online öğretmeöğrenme araçlarını gelecekte kullanmaya oldukça sıcak baktıkları ifade edilebilir.

\section{Tartışma ve Sonuç}


Derslerde bir öğretim materyali olarak Kahoot kullanımı hakkında öğretmen adaylarının görüşlerinin belirlenmesini amaçlayan bu nitel araştırmanın bulguları, içerik analizi ile çözümlenmiş ve ilgili alanyazınla birçok açıdan karşılaştırmalı sonuçlara ulaşılmıştır. Örneğin, kategorik açıdan katılımcı görüşlerinin büyük bir oranda Kahoot'un derslerde mutlaka kullanılması yönünde ve olumlu olduğu anlaşılmaktadır. Bu sonuç, Kahoot ve benzeri online öğretme-öğrenme teknolojilerinin derslerde kullanımını teşvik eden araştırma (Aleksıc-Maslac ve Ark., 2017; Alvarado, Coelho ve Dougherty, 2016; Avcı ve Coşkuntuncel, 2019; Damarwan ve Khairudin, 2017; Dellos, 2015; Johns, 2015; Licorish ve Ark., 2018; Sarkar, Ford ve Mando, 2017; Turan ve Göktaş, 2015; Twymana ve Heward, 2015; Yapıcı ve Karakoyun, 2017) sonuçlarıyla birebir örtüşmektedir. Bu durumu, tematik analiz sonrasında ortaya çıkan "Öğretim" temasının oldukça desteklediği ifade edilebilir. Zira öğretim teması altında, derslerde Kahoot kullanılmasının "Eğlence”li olduğu, “Tekrar-Pekiştirme ve Hatırlatma” imkânı sunduğu; ayrıca “Teknolojiyi İşe Koşma/Entegrasyon”u sağladığı ve öğrencilere “Keyif” verdiği anlaşılmaktadır. Kahoot kullanılmasının "Dikkati Çekme" yoluyla sıkılan hatta derslere katılmak istemeyen öğrencileri de motive ettiği ifade edilebilir. Bu sonuçlar, öncelikle alanyazında Aleksıc-Maslac ve arkadaşlarının iddia ettikleri pozitif dalga (2017) etkisini ve Iwamoto ve arkadaşlarının (2017) savundukları Kahoot'un öğrenci performansını artırmadaki rolünü destekler niteliktedir. Ayrıca öğretim yöntemi olarak sunuş yolu stratejisini benimseyen öğretim elemanları için öğretimi “Bireyselleştirme”ye sağladığı katkısıyla Kahoot'un, dersleri öğretmen adayları için nispeten sıkıcı olmaktan kurtaracak bir online öğretme-öğrenme aracı olma iddiasını sürdürdüğ̈ ifade edilebilir. Nitekim öğretmen adaylarının görüşleri doğrultusunda ulaşılan diğer iki temadan birinin "Etkili Öğrenme" ve diğerinin ise "Katılım" olmasının bu ifadeyi güçlendirdiği söylenebilir.

Öğretmen adaylarının yaklaşık \%47'si, etkili öğrenme adına derslerde Kahoot kullanımının, konuları daha iyi "Anlama” ve "Kavrama”larını sağladığı; "İstek” ve “Konsantrasyon”larını diğer bir deyişle "Motivasyon”larını artırdığg iddiasındadırlar. Ve Bu iddia Wang ve Lieberoth'un (2016) çalışmalarından elde ettikleri sonuçlarla çok büyük oranda örtüşmektedir. Ayrıca öğretmen adayları arasında "Eksiklerini Görme” yoluyla "Hızlı" ve "Kolaylıkla" daha iyi öğrendiklerini beyan eden katılımcılar da vardır. Derse karşı daha fazla "Merak"la yaklaştıklarını, derslerde Kahoot kullanımının kendi öğrenmeleri üzerinde "Bilginin 
Yükseköğretimde Kahoot Kullanmak Ya Da Kullanmamak: Öğretmen Adaylarının Kahoot'la Öğretime Yönelik Görüşleri

Kalıcılığı” nı artırdığını vurgulayanların sayısı ise azımsanmayacak kadar fazladır. Bu bağlamda öğretmen adayları derslerde Kahoot kullanımının "Uyumu”, "Bilgiyi Ölçmeyi” ve okuldaki "Sınavlara Hazırlığgı" kolaylaştırdığını savunmaktadırlar. Burada özellikle sınıf yönetimi açısından önemli bir sonuç ise katılımcıların Kahoot'un derslerde kullanımının "Sınıf İçi Etkileşimi” iyileştirdiği yönündeki görüşleridir. Bu sonucun Sarkar, Ford ve Mando’nun (2017) çalışmalarında dijital yerlilerin sosyal öğrenme süreçlerinde Kahoot'la öğretimin etkilerine yapmış oldukları vurguyu destekler nitelikte olduğu belirtilebilir.

Kahoot'un derse "Katılımı" artırdığg yönündeki bulgular incelendiğinde ise öğretmen adaylarının, derste Kahoot'un kullanılması nedeniyle "Derslere Hazırlıklı” gelmeye başladıkları ve böylece derse "Aktif Katılım” gösterdikleri düşüncesinde oldukları sonucuna ulaşılmıştır. Buna göre katılımcıların yaklaşık \%22'si “Katılım” teması altında görüş bildirmişlerdir. Ayrıca bazı öğretmen adayları Kahoot'un dersteki "Yarışma" ve "Rekabet" ortamını körüklediği düşüncesini de bu tema altında paylaşmaktadırlar.

Diğer yandan kategorik açıdan Kahoot'un derslerde kullanılmasına; katılımcıların yaklaşık \%2'si kesinlikle kullanmam ve \% 33'ü gerektiği zaman kullanırım şeklinde görüş bildirmişlerdir. Dolayısıyla öğretmen adaylarının, en çok Kahoot'un internet tabanlı yani online bir öğretme-öğrenme aracı olması nedeniyle özellikle sınıf ortamında "İnternet” imkânlarının yeterli olmamasından yakındıkları belirtilebilir. Ayrıca Kahoot'un neden olduğu "Rekabetçi”" liğin sağlıksız bir ortam yarattığını, başka bir deyişle bir nevi stres kaynağı olduğunu öne süren katılımcıların olduğu da göz ardı edilmemelidir. Yükseköğretimde "dijital dönüşümün” sıklıkla ülkemizde de dillendiridiği bir dönemden geçilmektedir. $\mathrm{Bu}$ anlamda öncelikle üniversitelerimizdeki eduroam ve benzeri ortak paylaşımlı internet ağlarının öğrencilerin özellikle ders içi süreçlerde kullanımlarına uygun hale getirilmesinde fayda olduğu ifade edilebilir. Öğretim elemanlarının sınıf içinde oluşması muhtemel "Rekabetçi” koşulları iyi şekilde önceden analiz etmelerinin ve sınıfta bu koşulların yönetimi açısından kullanacakları stratejileri önceden belirlemelerinin öğretim sürecine katkı sağlayacağı ifade edilebilir.

Öğretmen adaylarının derslerde Kahoot'un daha etkili nasıl kullanılabileceğine ilişkin görüşleri doğrultusunda ulaşılan tematik bulgulara göre sırasıyla "İçerik, Kullanım, Zaman ve Görsellik" temalarının önemli olduğu, araştırmanın kayda değer bir diğer sonucudur. Bu doğrultuda katılımcılar, yaklaşık yüzde \%40 oranında Kahoot'un “İçerik” açısından daha zengin 
olabileceğine; diğer bir deyişle öğretim elemanının hazırladığı quizlerdeki soru sayısı ve tipinin artırılması gerektiğine, tüm derslerde "kullanılma"sı gerektiğine ve hatta her eğitim kademesinde kullanılmasının yarar sağlayacağına dikkat çekmişlerdir. Ayrıca öğretmen adaylarının, derslerde Kahoot için daha fazla "zaman” ayrılması gerektiği görüşünü savundukları belirtilebilir. Sesli sorular veya video ekleme seçeneklerinin çoğaltılmasının yararlı olacağını ifade eden katılımcıların da olduğu anlaşılmaktadır. Ancak burada araştırmacı tarafından "Eğitime Giriş" dersi süresince kullanılan Kahoot uygulamasının, ücretsiz paket özelliklerini taşıdığının, dolayısıyla özellik kısıtlamalarının bulunduğunun bilinmesinde yarar vardır.

Gelecekte Kahoot ve benzeri uygulamaları derslerinde kesinlikle kullanacağını belirten öğretmen adayı oranının yaklaşık \%65 ve gerektiği zaman kullanacağını belirten katılımcılarla birlikte bu oranın yaklaşık \%98'e ulaşmış olması ise ulaşılan sonuçlar açısından oldukça önemlidir. $\mathrm{Bu}$ anlamda, öğretmen adaylarının gelecekte Kahoot ve benzeri online öğretmeöğrenme araçlarıyla ders işlemeyi çok ciddi anlamda istedikleri söylenebilir.

Sonuç olarak araştırmanın derslerde bir öğretim materyali/online öğretme-öğrenme aracı olarak Kahoot kullanımı hakkında çalışma grubundaki öğretmen adaylarının olumlu görüş belirttikleri söylenebilir. Kahoot, araştırmaya katılan öğretmen adaylarının öğretim, etkili öğrenme ve derse katılımları üzerinde olumlu etkiler doğurmuştur. Ancak Kahoot kullanılırken içerik, kullanım, zaman ve görsellik öğelerine dikkat edilmelidir. Öğretmen adaylarının neredeyse tamamı Kahoot ve benzeri araçları gelecekte mesleklerini icra ederken kullanmak istediklerini beyan etmişlerdir. Bu anlamda özellikle yöneticiler, eğitim fakültelerinde internet alt yapısı sorunlarının çözümüne ayrılan zaman ve bütçenin artırılması yönünde adımlar atabilirler. Kahoot ve benzeri öğretim araçlarının derslerde etkin kullanımı konusunda fakülteler, öğretim üyelerine dönük farkındalık atölyeleri, seminerler, eğitim kursları düzenlenmesinde teşvik edici olabilirler. Konuya ilgi duyan araştırmacıların çok disiplinli bir yaklaşımla online yazılım, uygulama ve sınamaya dönük deneysel projelere yönelmeleri sağlanabilir.

\section{Kaynakça}

Aleksic-Maslac, K., Sinkovic, B., \& Vranesic, P. (2017). Influence of gamification on student engagement in education. International Journal of Education and Learning Systems, 2, 76-82. http://iaras.org/iaras/journals/ijels 
Yükseköğretimde Kahoot Kullanmak Ya Da Kullanmamak: Öğretmen Adaylarının Kahoot'la Öğretime Yönelik Görüşleri

Alvarado, N. C., Coelho, D. \& Dougherty, E. (2016). Mobile apps for ELLs: Supporting language learning with engaging digital tools. Argentinian Journal of Applied Linguistics, 4(1), 43-58.

Ares, A. M., Bernal, J., Nozal, M. J., Sánchez, F. J. \& Bernal, J. (2018). Results of the use of Kahoot! gamification tool in a course of Chemistry. $4^{\text {th }}$ International Conference on Higher Education Advances (HEAd'18) Universitat Polit 'ecnica de Val'encia, Val'encia, DOI: http://dx.doi.org/10.4995/HEAd18.2018.8179

Avcı, E. \& Coşkuntuncel, O. (2019). Middle school teachers' opinions about using Vustat and Tinkerplots in the data processing in middle school mathematics. Pegem Eğitim ve Öğretim Dergisi, 9(1), 01-36.

Baltacı, A. (2018). Nitel araştirmalarda örnekleme yöntemleri ve örnek hacmi sorunsali üzerine kavramsal bir inceleme. $B E \ddot{U}$ SBE Derg., 7(1), 231-274.

Bicen, H. \& Kocakoyun, S. (2017). Determination of university students' most preferred mobile application for gamification. World Journal on Educational Technology: Current Issues. 9(1), 18-23.

Boden, G. M., \& Hart, L. (2018). Kahoot-Game Based Student Response System. Compass: Journal of Learning and Teaching, 11(1).

Buzko, V. L., \& Echkalo, Y. V. (2017). Heimifikatsiia yak zasib formuvannia piznavalnoho interesu u navchanni fizyky (Gamification as a mean of forming of cognitive interest in physics teaching). New computer technology, 15, 171-175.

Büyüköztürk, Ş. S (2012). Örnekleme yöntemleri. (http://w3.balikesir.edu.tr/ msackes/wp/wpcontent/uploads/2012/03/BAYFinalKonulari.pdf adresinden 17.09.2019 tarihinde indirilmiştir).

Damarwan, E. S., \& Khairudin, M. (2017). Development of an interactive learning media to improve competencies. Advances in Social Science, Education and Humanities Research, 102, 24-27.

Dellos, R. (2015). Kahoot! A digital game resource for learning. International Journal of Instructional Technology and Distance Learning, 12(4), 49-52.

Graham, K. (2015). TechMatters: Getting into Kahoot! (s): Exploring a game-based learning system to enhance student learning. LOEX Quarterly, 42(3). Available at: https://commons.emich.edu/loexquarterly/vol42/iss3/4 
Johns, K. (2015). Engaging and assessing students with technology: a review of Kahoot! Delta Kappa Gamma Bulletin, 81(4), 89.

Licorish, S. A., Owen, H. E., Daniel, B. \& George, J. L. (2018). Students' perception of Kahoot!'s influence on teaching and learning. Research and Practice in Technology Enhanced Learning, 13(9), 1-23. https://doi.org/10.1186/s41039-018-0078-8

Martins, E. R., Geraldes, W. B., Afonseca, U. R., \& Gouveia, L. M. B. (2019). Using kahoot as a learning tool. In Information Systems for Industry 4.0 (pp. 161-169). Springer, Cham.

Medina, E. G. L. \& Hurtado, C. P. R. (2017). Kahoot! A digital tool for learning vocabulary in a language classroom. Revista Publicando, 12(1), 441-449.

Miles, M. B. \& Huberman, A. M. (1994). Qualitative data analysis: An expanded sourcebook. New York: Sage.

Saban, A. (2009). Öğretmen adaylarinin öğrenci kavramina ilişkin sahip olduklari zihinsel imgeler. Türk Eğitim Bilimleri Dergisi, 7(2), 281-326.

Sarkar, N., Ford, W., \& Manzo, C. (2017). Engaging digital natives through social learning. Systemics, Cybernetics and Informatics, 15(2), 1-4.

Stige, S. H. (2017). «Kahoot!» as a tool for adjusting teaching to match students' knowledge level and promoting active learning in a lecture setting. In Program for universitetspedagogikk, Universitetet i Bergen, [online] Available: http://hdl.handle.net/1956/15649

Tan, D. A. L., Lee, B. C., Ganapathy, M., \& Kasuma, S. A. A. (2019). Language Learning in the 21st Century: Malaysian ESL Students' Perceptions of Kahoot! International Journal of Virtual and Personal Learning Environments (IJVPLE), 9(2), 55-71.

Tsihouridis, C., Vavougios, D. \& Ioannidis, G. (2017). Assessing the learning process playing with Kahoot - a study with upper secondary school pupils learning electrical circuits. ICL2017 - 20 International Conference on Interactive Collaborative Learning, 27-29 September 2017, Budapest, Hungary.

Twyman, J. S. \& Heward, W. L. (2016). How to improve student learning in every classroom now. International Journal of Educational Research, 87, 78-90. http://dx.doi.org/10.1016/j.ijer.2016.05.007

Turan, Z. \& Göktaş, Y. (2015). Yüksek.ğretimde yeni bir yaklaşım: Öğrencilerin ters yüz sınıf yöntemine ilişkin görüşleri. Yükseköğretim ve Bilim Dergisi, 5(2), 156-164. DOI: 10.5961/jhes.2015.118 
Yükseköğretimde Kahoot Kullanmak Ya Da Kullanmamak: Öğretmen Adaylarının Kahoot'la Öğretime Yönelik Görüşleri

Iwamoto, D. H., Hargis, J., Taitano, E. J., \& Vuong, K. (2017). Analyzing the efficacy of the testing effect using kahoot ${ }^{\mathrm{TM}}$ on student performance. Turkish Online Journal of Distance Education, 18(2), 80-93.

Yapıc1, İ. Ü. \& Karakoyun, F. (2017). Gamification in biology teaching: A sample of Kahoot application. Turkish Online Journal of Qualitative Inquiry (TOJQI), 8(4), 396-414. DOI: 10.17569/tojqi.335956

Wang, A. I. \& Lieberoth, A. (2016). The effect of points and audio on concentration, engagement, enjoyment, learning, motivation, and classroom dynamics using Kahoot! $10^{\text {th }}$ European Conference on Game Based Learning (ECGBL 2016), At Paisley, Scotland.

Yıldırım, A. \& Şimşek, H. (2006). Sosyal bilimlerde nitel araştırma yöntemleri (5. Baskı). Ankara: Seçkin Yayıncılık.

Zarzycka-Piskorz, E. (2016). Kahoot it or not? Can games be motivating in learning grammar? Teaching English with Technology, 16(3), 17-36, http://www.tewtjournal.org 